\title{
Sistem Pendukung Keputusan Kenaikan Jabatan menggunakan Metode Profile Matching (Studi Kasus PT. Beyf Bersaudara)
}

\author{
Alwendi \\ Jurusan Teknik Informatika, Fakultas Teknik, Universitas Graha Nusantara \\ Jl. Sadabuan No 17 Padangsidimpuan Sumatera Utara \\ *Email: alwendi60@gmail.com
}

\begin{abstract}
Abstrak
Jika berbicara organisasi atau perusahaan, terdapat beberapa faktor penting yang dapat menentukan maju atau mundurnya organisasi atau perusahaan tersebut, di antaranya adalah peran pegawai. Pegawai yang mempunyai kualitas tinggi akan sangat membantu perusahaan dalam mencapai tujuannya. Perusahaan dapat memberikan penghargaan kepada pegawai yang dianggap berprestasi berupa kenaikan jabatan. Penelitian ini mengangkat studi kasus implementasi analisis gap untuk sistem pendukung keputusan kenaikan jabatan pada PT. Beyf Bersaudara. Saat ini proses kenaikan jabatan pegawai yang terdapat pada PT. Beyf Bersaudara belum dapat memenuhi kebutuhan yang diinginkan karena masih dilakukan secara manual. Pengumpulan data penelitian menggunakan teknik observasi, wawancara, dan studi pustaka. Metodologi pengembangan sistem yang digunakan adalah metodologi terstruktur dengan model pengembangan System Development Life Cycle (SDLC) dan perancangan model yang digunakan adalah model Pencocokan Profil (profile matching) dengan metode perhitungan Pemetaan Gap Kompetensi serta PHP dan MySQL sebagai alat pengkodean komputer. Sistem Pendukung Keputusan ini dapat menjadi solusi dalam pengambil keputusan untuk menentukan perhitungan nilai kenaikan jabatan.
\end{abstract}

Kata kunci: GAP, MySQL, PHP, SDLC (System Development Life Cycle), SPK

\section{PENDAHULUAN}

\subsection{Latar belakang}

Jika berbicara organisasi atau perusahaan, terdapat beberapa faktor penting yang dapat menentukan maju atau mundurnya organisasi atau perusahaan tersebut, di antaranya adalah peran pegawai. Seorang pegawai wajib melakukan pekerjaan yang menuju pada kemajuan perusahaan dan tidak boleh melakukan aktivitas yang bertujuan merugikan perusahaan. Pendidikan dan pelatihan adalah usaha yang terencana dari sebuah perusahaan baik itu perusahaan pemerintah maupun non-pemerintah, untuk meningkatkan pengetahuan, keterampilan dan kemampuan pegawai. Pegawai yang mempunyai kualitas tinggi akan sangat membantu perusahaan dalam mencapai tujuannya. Perusahaan dapat memberikan penghargaan kepada pegawai yang dianggap berprestasi. Penghargaan tersebut bisa berupa kenaikan jabatan, golongan atau perencanaan karir. Cara tersebut dapat memberikan semangat kepada pegawai untuk bekerja lebih baik lagi.
Jabatan merupakan sekelompok posisi yang hampir sama dalam suatu badan, lembaga, atau perusahaan (Moekijat, 2008). Bagi pegawai, hasil penilaian dapat digunakan untuk menjadi umpan balik terhadap prestasi kerja, sehingga memiliki dasar pertimbangan untuk perencanaan pengembangan karirnya. Sedangkan di sisi lain, hasil penilaian ini dapat digunakan perusahaan untuk melandasi pengambilan keputusan dalam hal sistem pemberian imbalan (kompensasi), kenaikan jabatan, pelatihan dan perencanaan karir.

Berdasarka hasil observasi yang ada, kenaikan jabatan PT. Beyf Bersaudara pada dasarnya masih bersifat manual, tidak adanya proses penilaian kinerja yang dilakukan, tidak sesuai dengan kenyataan dan melalui proses yang sangat rumit, seperti adanya pegawai yang dinilai dari satu kriteria saja, tetapi langsung mendapatkan kenaikan jabatan, padahal pegawai tersebut belum tentu unggul pada kriteria-kriteria yang lainnya, tidak adanya standar baku atau bobot nilai yang pasti dalam menentukan kualitas pegawai, dan tidak adanya sistem yang dapat memberikan 
alternatif solusi dalam penilaian kinerja pegawai untuk kenaikan jabatan.

Untuk meminimalisir hal tersebut, maka perlu adanya suatu sistem yang dapat memudahkan General Manager dalam mengambil keputusan kenaikan jabatan. Jika proses pengambilan keputusan ini dibantu oleh sebuah Sistem Pendukung Keputusan yang terkomputerisasi, diharapkan subyektifitas dalam pengambilan keputusan dapat dikurangi dan dapat diganti dengan pelaksanaan seluruh kriteria-kriteria untuk seluruh pegawai. Sehingga, diharapkan pegawai dengan kemampuan (pertimbangan lain) terbaiklah yang terpilih.

Sistem Pendukung Keputusan (SPK) merupakan sebuah sistem yang dimaksudkan untuk mendukung para pengambil keputusan manajerial dalam keputusan semi terstruktur. SPK ditujukkan untuk menjadi alat bantu bagi para pengambil keputusan untuk memperluas kapabilitas para pengambil keputusan tersebut, namun tidak untuk menggantikan penilaian.

\subsection{Tujuan Penelitian} yaitu:

Adapun tujuan diadakan penelitian ini

1. Merancang Sistem Pendukung Keputusan untuk kenaikan jabatan.

2. Membuat perancangan model pencocokan profil untuk proses penilaian kualitas kinerja pegawai.

3. Membuat rancang bangun Sistem Pendukung Keputusan yang dapat digunakan sebagai alat bantu pengambilan keputusan mengenai kenaikan jabatan yang berdasarkan pada penilaian kualitas pegawai.

\section{TINJAUAN PUSTAKA}

\subsection{Sistem Pendukung Keputusan (SPK)}

Definisi awal Sistem Pendukung

Keputusan adalah sebagai sebuah sistem yang dimaksudkan untuk mendukung para pengambil keputusan manajerial dalam situasi keputusan semiterstruktur. Sistem Pendukung Keputusan dimaksudkan untuk menjadi alat bantu bagi para pengambil keputusan untuk memperluas kapabilitas mereka, namun tidak untuk menggantikan penilaian mereka. SPK ditujukan untuk keputusan-keputusan yang memerlukan penilaian atau pada keputusankeputusan yang sama sekali tidak dapat didukung oleh algoritma .
Tabel 1. Konsep yang Mendasari Definisi SPK

\begin{tabular}{ll}
\hline Sumber & SPK yang didefinisikan \\
\hline $\begin{array}{l}\text { Little } \\
(1970)\end{array}$ & $\begin{array}{l}\text { Fungsi sistem, karakteristik } \\
\text { antar muka }\end{array}$ \\
\hline $\begin{array}{l}\text { Alter } \\
(1980)\end{array}$ & $\begin{array}{l}\text { Fungsi sistem, karakteristik } \\
\text { antar muka }\end{array}$ \\
\hline $\begin{array}{l}\text { Bonczek } \\
(1980)\end{array}$ & Komponen-komponen \\
\hline $\begin{array}{l}\text { Keen } \\
(1980)\end{array}$ & Proses pengembangan \\
\hline
\end{tabular}

Dari beberapa definisi pengambilan keputusan yang ditemukan, dapat dirangkum bahwa pengambilan keputusan di dalam suatu organisasi merupakan hasil suatu proses komunikasi dan partisipasi yang terus menerus dari keseluruhan organisasi. Hasil keputusan tersebut dapat merupakan pernyataan yang disetujui antar alternatif atau antar prosedur untuk mencapai tujuan tertentu. Pendekatannya dapat dilakukan, baik pendekatan yang bersifat individual/kelompok. Sentralisasi/desentralisasi, partisipasi/tidak berpartisipasi, maupun demokratis / konsensus.

Di balik suatu keputusan terdapat prosedur, yaitu pertama-tama pembuat keputusan mengidentifikasi masalah, mengklarifikasi tujuan-tujuan khusus yang diinginkan, memeriksa berbagai kemungkinan untuk mencapai tujuan yang telah ditetapkan, dan mengakhiri proses itu dengan menetapkan pilihan bertindak. Atau dengan kata lain, suatu keputusan didasarkan atas fakta dan nilai (facts and values). Keduanya sangat penting, tetapi nampaknya fakta lebih mendominasi nilai-nilai dalam pengambilan keputusan.

Pada akhirnya dapat dikatakan bahwa setiap keputusan itu bertolak dari beberapa kemungkinan atau alternatif untuk dipilih. Setiap alternatif membawa konsekuensikonsekuensi. Ini berarti, sejumlah alternatif itu berbeda satu dengan yang lain mengingat perbedaan dari konsekuensi-konsekuensi yang akan ditimbulkannya. Pilihan yang dijatuhkan pada alternatif itu harus dapat memberikan kepuasan karena kepuasan merupakan salah satu aspek paling penting dalam keputusan. Model yang menggambarkan proses pengambilan keputusan. Proses ini terdiri dari tiga fase, yaitu:

\section{Intelligence}

Tahap ini merupakan proses penelusuran dan pendeteksian dari lingkup problematika serta proses pengenalan masalah. Data 
masukan diperoleh, diproses, dan diuji dalam rangka mengidentifikasi masalah.

2. Design

Tahap ini merupakan proses menemukan, mengembangkan dan menganalisis alternatif tindakan yang bisa dilakukan. Tahap ini meliputi proses untuk mengerti masalah, menurunkan solusi dan menguji kelayakan solusi.

3. Choice

Pada tahap ini dilakukan proses pemilihan diantara berbagai alternatif indakan yang mungkin dijalankan. Hasil pemilihan tersebut kemudian diimplementasikan dalam proses pengambilan keputusan.

\subsection{Karakteristik Sistem Pendukung Keputusan (SPK) \\ SPK memiliki karakteristik sebagai} berikut:

1. Menawarkan keluwesan, kemudahan beradaptasi, dan tanggapan yang cepat.

2. Memungkinkan pemakai memulai dan mengendalikan masukan dan keluaran.

3. Dapat dioperasikan dengan sedikit atau tanpa bantuan pemrogram profesional.

4. Menyediakan dukungan untuk keputusan dan permasalahan yang solusinya tak dapat ditentukan di depan.

5. Menggunakan analisis data dan perangkat pemodelan yang canggih.

\subsection{Jabatan}

1. Edwin. B. flippo. Principles of Personnel Management. McGraw-Hill Book Company. Inc., New York. Toronto, London. 1961.

A job can be now defined as a group of positions that are similar as to kind and level of work. Sekarang suatu jabatan dapat dirumuskan sebagai sekelompok posisi yang mirip, baik mengenai jenis maupun mengenai tingkat pekerjaannya.

2. Dale Yoder. Personnel Principles and policies Modern Manpower

Management.second Edition, Maruzen Company, Ltd., Tokyo, tanpa tahun.

A job is a collections of tasks, duties, and responsibilities which, as a whole, is regarded as the usual assignment to a single employee. A job may include many position is a job or series of tasks performed by a single, individual employee. Thus, an employee has his position, but many positions may be indentical or so much alike as to constitute a single job. Suatu jabatan adalah sekelompok tugas, kewajiban, dan tanggung jawab, yang dari definisi-definisi tersebut di atas dapat ditarik kesimpulan bahwa suatu jabatan adalah sekelompok posisi yang hampir sama dalam suatu badan, lembaga, atau perusahaan. Dalam rumusan ini dikatakan hampir sama, karena pada hakikatnya tidak ada dua posisi yang tepat sama dalam tugas, tanggung jawab, dan syarat-syarat kerjanya. Pekerjaan yang dilakukan oleh dua orang pesuruh misalnya tidak akan persis sama banyaknya atau sama beratnya (Moekijat, 2008).

\subsection{Pengukuran Kinerja}

Pengukuran terhadap kinerja perlu dilakukan untuk mengetahui apakah selama pelaksanaan kinerja terdapat deviasi dari rencana yang telah ditentukan, atau apakah kinerja dapat dilakukan sesuai jadwal waktu yang ditentukan, atau apakah hasil kinerja yang telah tercapai sesuai dengan yang diharapkan. Untuk melakukan pengukuran tersebut, diperlukan kemampuan untuk mengukur kinerja sehingga diperlukan adanya ukuran kinerja. Pengukuran kinerja hanya dapat dilakukan terhadap kinerja yang nyata dan terukur. Apabila kinerja tidak dapat diukur, tidak dapat dikelola. Untuk dapat memperbaiki kinerja, perlu diketahui seperti apa kinerja saat ini. Apabila kinerja deviasi dapat diukur, dapat diperbaiki. Pengukuran hanya berkepentingan untuk mengukur apa yang penting dan relevan. Untuk itu, perlu tentang apa yang dikatakan penting dan relevan sebelum menentukan ukuran apa yang harus digunakan. Hal-hal yang diukur tergantung pada apa yang dianggap penting oleh stakeholders dan pelanggan. Pengukuran mengatur keterkaitan antara strategi berorientasi pelanggan dan tujuan dengan tindakan.

\subsection{Model Pencocokan Profil (Profile Matching)}

Maksud dari pencocokan profil (profile matching) adalah sebuah mekanisme pengambilan keputusan dengan mengasumsikan bahwa terdapat variabel prediktor yang ideal yang harus dimiliki oleh pegawai, bukannya tingkat minimal yang harus dipenuhi atau 
dilewati. Dalam pencocokan profil, dilakukan identifikasi terhadap kelompok karyawan yang baik maupun buruk. Para karyawan dalam kelompok tersebut diukur menggunakan beberapa kriteria penilaian. Jikalau pelaksana yang baik memperoleh skor yang berbeda dari pelaksana yang buruk atau sebuah karakteristik, maka variabel tersebut berfaedah untuk memilih pelaksana yang baik. Begitu beberapa variabel yang membedakan antara pelaksana-pelaksana yang baik dan buruk telah teridentifikasi, profil ideal mungkin memiliki kecerdasan rata-rata, kepekaan sosial yang baik, kebutuhan rendah untuk mendominasi orang lain, dan tingkat kemampuan perencanaan yang tinggi. Dalam pencocokan profil, pegawai yang mendekati profil ideal ialah seorang pegawai yang berhasil (Kusrini, 2007).

\subsection{Pemetaan Gap Kompetensi}

Gap merupakan suatu alat yang digunakan untuk mengevaluasi kinerja. Metode ini merupakan salah satu metode yang umum digunakan dalam pengelolaan manajemen suatu lembaga. Secara harfiah kata "gap" mengindikasikan adanya suatu perbedaan (disparity) antara satu hal dengan hal lainnya.

Gap yang dimaksud adalah beda antara profil jabatan dengan profil karyawan atau dapat ditunjukkan pada rumus Gap $=$ Profil Karyawan - Profil Jabatan . Sedangkan untuk pengumpulan gap-gap yang terjadi itu sendiri pada tiap aspeknya mempunyai perhitungan yang berbeda-beda (Kusrini, 2007).

Aspek penilaian meliputi tiga aspek, yaitu (Kusrini, 2007):

1. Aspek Kecerdasan atau Intelektual (Menggunakan Tes IST)

Hal-hal yang diukur dalam aspek kecerdasan kerja adalah kecerdasan, kepandaian, dan kemampuan problem solving.

2. Aspek sikap Kerja (Menggunakan Tes Pauli) Hal-hal yang diukur dalam aspek sikap kerja adalah kecenderungan berperilaku dalam bekerja, dan hasil sebagai fungsi motivasi dan kemampuan.

3. Aspek Perilaku (Menggunakan Tes Pauli)

Hal-hal yang diukur dalam aspek perilaku adalah perilaku manusia yang muncul sebagai reaksi terhadap suatu lingkungan yang bersifat antagonistik hingga menyenangkan dalam mengantisipasi kedua lingkungan tersebut.

\subsection{Perhitungan dan Pengelompokan Core dan Secondary Factor}

Setiap aspek dikelompokkan menjadi 2 kelompok, yaitu kelompok core factor dan secondary factor. Perhitungan core factor ditunjukkan dengan menggunakan rumus dibawah ini (Kusrini, 2007):

$$
\boldsymbol{N C F}=\frac{\sum \mathrm{NC}(\mathrm{i}, \mathrm{s}, \mathrm{p})}{\sum \mathrm{IC}}
$$

Keterangan:

NCF
NC (i,s,p) : Jumlah total nilai core factor
(intelektual, sikap kerja,
perilaku)

IC : Jumlah item core factor

Perhitungan secondary factor dapat ditunjukkan dengan rumus berikut:

$$
\boldsymbol{N S F}=\frac{\sum \mathrm{NS}(\mathrm{i}, \mathrm{s}, \mathrm{p})}{\sum \mathrm{IS}}
$$

NsF :Nilai rata-rata secondary factor

NS (i,s,p) :Jumlah total nilai secondary factor (intelektual, sikap kerja, perilaku)

IS : :Jumlah item secondary factor

\subsection{Perhitungan Nilai Total}

Dari hasil perhitungan setiap aspek di atas, berikutnya dihitung nilai total berdasarkan presentase dari core dan secondary yang diperkirakan berpengaruh terhadap kinerja tiaptiap profil. Perhitungan nilai total dapat dilihat pada rumus dibawah ini (Kusrini, 2007):

$$
(x) \% N C F(i, s, p)+(x) \% N S F(i, s, p)=N(i, s, p)
$$

Keterangan:

NCF (i,s,p) : Nilai rata-rata core factor (Intelektual, Sikap Kerja, Perilaku)

NSF(i,s,p) :Nilai rata-rata secondary factor (Intelektual, Sikap Kerja,Perilaku)

$\mathrm{N}(\mathrm{i}, \mathrm{s}, \mathrm{p}) \quad$ : Nilai total dari aspek (Intelektual, Sikap Kerja, Perilaku)

(x)\% : Nilai persen yang dimasukkan

\subsection{Perhitungan Penentuan Rangking}


Hasil akhir dari proses pencocokan profil adalah ranking dari kandidat yang diajukan untuk mengisi jabatan tertentu. Penentuan ranking mengacu pada hasil perhitungan tertentu. Perhitungan tersebut bisa ditunjukkan dengan rumus di bawah ini (Kusrini, 2007):

$$
\text { Ranking }=(\%) \mathbf{N i}+(\%) \mathbf{N s}+(\%) \mathbf{N p}
$$

Keterangan:

$\mathrm{Ni} \quad$ : Nilai Kapasitas Intelektual

Ns : Nilai Sikap Kerja

$\mathrm{Np} \quad$ : Nilai Perilaku

(x)\% : Nilai persen yang dimasukkan

\section{METODE PENELITIAN}

\subsection{Metodologi Pengumpulan Data}

\section{Studi Pustaka}

Studi pustaka merupakan proses umum yang dilalui untuk mendapatkan teori terlebih dahulu. Mencari kepustakaan yang terkait adalah tugas yang segera dilakukan, lalu menyusunnya secara teratur dan rapi untuk dipergunakan dalam keperluan penelitian. Kajian pustaka memiliki beberapa fungsi sebagai berikut:

2. Studi Lapangan

Studi lapangan dapat dilakukan dengan berbagai cara, yaitu:

a. Pengamatan (Observasi)

Observasi atau pengamatan (observation) merupakan salah satu teknik pengumpulan data I fakta (fact finding technique) yang cukup efektip untuk mempelajari suatu sistem. Observasi adalah pengamatan langsung suatu kegiatan yang sedang dilakukan. Pada waktu melakukan observasi, analis sistem dapat ikut juga berpartisipasi atau hanya mengamati saja orang-orang yang sedang melakukan suatu kegiatan tertentu yang diobservasi (Jogiyanto, 2005).

b. Wawancara (Interview)

Wawancara (Interview) telah diakui sebagai teknik pengumpulan data/fakta yang penting dan banyak dilakukan dalam pengembangan sistem informasi. Wawancara memungkinkan analisa sistem sebagai pewawancara (interviewer) untuk mengumpulkan data secara tatap muka langsung dengan orang yang diwawancarai ( interview). Seperti halnya teknik pengumpulan data yang lain wawancara bukanlah teknik yang terbaik untuk semua situasi (Jogiyanto, 2005).

\section{c. Studi Literatur}

Sejenis Pengumpulan data biasanya diawali dengan mengumpulkan informasi yang berhubungan dengan masalah penelitian. Informasi-informasi tersebut diperoleh melalui peninjauan literatur yang relevan.

\section{HASIL DAN PEMBAHASAN}

\subsection{Flowchart Pencocokan Profil}

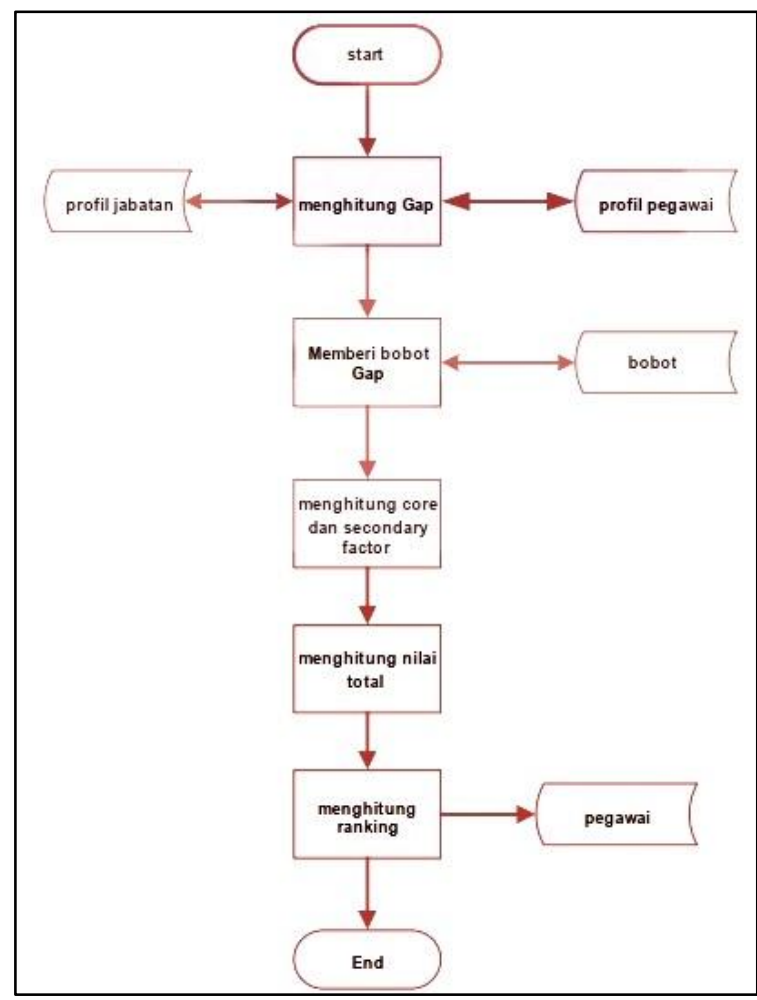

Gambar 1. Flowchart Profile Matching

\subsection{Pencocokan Profil}

\section{Pemetaan GAP Kompetensi}

GAP yang dimaksud disini adalah perbedaan antara profil jabatan dan profil pegawai atau bisa dirunjukan dengan rumus dibawah ini

\section{GAP $=$ Profil pegawai - Profil Jabatan}

Berikut ini contoh perhitungan GAP untuk masing-masing aspek :

1. Kapasitas Intelektual

Pada aspek ini dilakukan proses perhitungan GAP antara profil pegawai dan profil jabatan untuk masing-masing faktor penilaian perhitngan bisa dilihat seperti tabel dibawah ini.

Tabel 2. Nilai Pegawai 


\begin{tabular}{llllllllllll}
\hline $\begin{array}{l}\text { N } \\
\text { o }\end{array}$ & Pegawai & $\mathbf{1}$ & $\mathbf{2}$ & $\mathbf{3}$ & $\mathbf{4}$ & $\mathbf{5}$ & $\mathbf{6}$ & $\mathbf{7}$ & $\mathbf{8}$ & $\mathbf{9}$ & IQ \\
\hline 1 & 0010 & 3 & 2 & 4 & 2 & 2 & 3 & 2 & 3 & 4 & 3 \\
2 & 0017 & 3 & 4 & 3 & 3 & 2 & 2 & 4 & 2 & 4 & 4 \\
3 & 0020 & 4 & 5 & 4 & 3 & 5 & 4 & 3 & 4 & 5 & 4 \\
4 & 0022 & 3 & 4 & 3 & 3 & 4 & 5 & 2 & 5 & 4 & 3 \\
5 & 0032 & 3 & 4 & 4 & 2 & 2 & 4 & 3 & 3 & 3 & 2 \\
\hline
\end{tabular}

Tabel 3. Bobot Nilai Jabatan

\begin{tabular}{lllllllllll}
\hline & $\mathbf{1}$ & $\mathbf{2}$ & $\mathbf{3}$ & $\mathbf{4}$ & $\mathbf{5}$ & $\mathbf{6}$ & $\mathbf{7}$ & $\mathbf{8}$ & $\mathbf{9}$ & IQ \\
\hline $\begin{array}{l}\text { Profi } \\
\text { Jabatan }\end{array}$ & 4 & 4 & 3 & 3 & 5 & 4 & 4 & 5 & 3 & 4 \\
\hline
\end{tabular}

Tabel 4. Hasil GAP Kapasitas intelektual

\begin{tabular}{|l|l|l|l|l|l|l|l|l|l|l|l|}
\hline No & Id pegawai & $\mathbf{1}$ & $\mathbf{2}$ & $\mathbf{3}$ & $\mathbf{4}$ & $\mathbf{5}$ & $\mathbf{6}$ & $\mathbf{7}$ & $\mathbf{8}$ & $\mathbf{9}$ & IQ \\
\hline 1 & 0010 & -1 & -2 & 1 & -1 & -3 & -1 & -2 & -2 & 1 & -1 \\
\hline 2 & 0017 & -1 & 0 & 0 & 0 & -3 & -2 & 0 & -3 & 1 & 0 \\
\hline 3 & 0020 & 0 & 1 & 1 & 0 & 0 & 0 & -1 & -1 & 2 & 0 \\
\hline 4 & 0022 & -1 & 0 & 0 & 0 & -1 & 1 & -2 & 0 & 1 & -1 \\
\hline 5 & 0032 & -1 & 0 & 1 & -1 & -2 & 0 & -1 & -1 & 0 & -2 \\
\hline
\end{tabular}

Keterangan:

1 : Common Sense

2 : Verbalisasi Ide

3 : Sistematika Berfikir

4 : Penalaran dan solusi Real

5 : Konsentrasi

6 : Logika Praktis

7 : Fleksibilitas Berfikir

8 : Imajinasi Kreatif

9 : Antisipasi

10 : Potensi Kecerdasan

\section{Sikap Kerja}

Tabel 5. Nilai Pegawai

\begin{tabular}{llllllll}
\hline $\begin{array}{l}\text { N } \\
\text { ID }\end{array}$ & $\begin{array}{c}\text { EP } \\
\text { Pega }\end{array}$ & $\begin{array}{l}\text { KT } \\
\mathbf{2}\end{array}$ & $\begin{array}{l}\text { KH_ } \\
\mathbf{2}\end{array}$ & $\begin{array}{l}\mathbf{P P}_{-} \\
\mathbf{2}\end{array}$ & $\begin{array}{l}\text { DB_ } \\
\mathbf{2}\end{array}$ & $\begin{array}{c}\text { VP } \\
\mathbf{2}\end{array}$ \\
\hline 1 & 0010 & 2 & 3 & 4 & 2 & 1 & 1 \\
2 & 0017 & 3 & 2 & 3 & 4 & 3 & 2 \\
3 & 0020 & 4 & 5 & 4 & 4 & 5 & 3 \\
4 & 0022 & 4 & 3 & 4 & 3 & 5 & 3 \\
5 & 0032 & 2 & 3 & 3 & 3 & 2 & 2 \\
\hline
\end{tabular}

Tabel 6. Bobot Nilai Jabatan

\begin{tabular}{lllllll}
\hline & $\mathbf{E P}_{-}$ & $\mathbf{K T}$ & $\mathbf{K H}$ & $\mathbf{P P}_{-}$ & $\mathbf{D B}_{-}$ & $\mathbf{V P}_{-}$ \\
& $\mathbf{2}$ & $\mathbf{2}$ & $\mathbf{2}$ & $\mathbf{2}$ & $\mathbf{2}$ & $\mathbf{2}$ \\
\hline Profil & 3 & 4 & 3 & 2 & 5 & 4 \\
Jabatan & & & & & & \\
\hline
\end{tabular}

Tabel 7. Hasil GAP Sikap Kerja

\begin{tabular}{llllllll}
\hline No & Id pegawai & EP_2 & KT_2 & KH_2 & PP_2 & DB_2 & VP_2 \\
\hline 1 & 0010 & -1 & -1 & 1 & 0 & -4 & -3 \\
2 & 0017 & 0 & -2 & 0 & 2 & -2 & -2 \\
3 & 0020 & 1 & 1 & 1 & 2 & 0 & -1 \\
4 & 0022 & 1 & -1 & 1 & 1 & 0 & -1 \\
5 & 0032 & -1 & -1 & 0 & 1 & -3 & -2 \\
\hline
\end{tabular}

Keterangan

EP_2 : Energi Psikis

KT_2 : Ketelitian dan Tanggung Jawab

KH_2: Kehati-hatian

PP_2 : Pengendalian Perasaan

DB_2 : Dorongan Berprestasi

VP_2 : Vitalitas dan Perencanaan

3. Perilaku

Tabel 8. Nilai Pegawai

\begin{tabular}{|l|l|l|l|l|l|}
\hline No & Id pegawai & D_3 & I_3 & S_3 & C_3 \\
\hline 1 & 0010 & 3 & 3 & 4 & 3 \\
\hdashline 2 & 0017 & 3 & 3 & 4 & 3 \\
\hdashline 3 & 0020 & 5 & 5 & 5 & 2 \\
\hdashline 4 & 0022 & 3 & 3 & 4 & 2 \\
\hdashline 5 & 0032 & 4 & 3 & 4 & 5 \\
\hline
\end{tabular}

Tabel 9. Bobot Nilai Jabatan

\begin{tabular}{|l|l|l|l|l|}
\hline & D_3 & I_3 & S_3 & C_3 \\
\hline Profil Jabatan & 4 & 5 & 3 & 3 \\
\hline
\end{tabular}

Tabel 10. Hasil GAP Prilaku

\begin{tabular}{|l|l|l|l|l|l|}
\hline No & Idpegawai & D_3 & I_3 & S_3 & C_3 \\
\hline 1 & 0010 & -1 & -2 & 1 & 0 \\
\hdashline 2 & 0017 & -1 & -2 & 1 & 0 \\
\hdashline 3 & 0020 & 1 & 0 & 2 & -1 \\
\hdashline 4 & 0022 & -1 & -2 & 1 & -1 \\
\hdashline 5 & 0032 & 0 & -2 & 1 & 2 \\
\hline
\end{tabular}

keterangan

D_3 : Dominance (Kekuasaan)

I_3 : Influences (Pengaruh)

S_3 : Steadiness (Keteguhan Hati)

C_3 : Compliance (Pemenuhan)

\section{Perhitungan Nilai Total}


Dari hasil setiap perhitungan setiap aspek, berikutnya dihitung nilai total berdasarkan persentase dari core \& secondary factor yang diperkirakan berpengaruh terhadap kinerja tiap-tiap profil

$$
(\mathbf{x}) \% \mathbf{N C F}(\mathbf{i}, \mathbf{s}, \mathbf{p})+(\mathbf{x}) \% \mathbf{N S F}(\mathbf{i}, \mathbf{s}, \mathbf{p})=\mathbf{N}(\mathbf{i}, \mathbf{s}, \mathbf{p})
$$

\section{1) Kapasitas intelektual}
a. Pegawai 1
$\mathrm{Ni}=(60 \% \times 3)+(40 \% \times 4,2)=3,48$
b. Pegawai 2
$\mathrm{Ni}=(60 \% \times 3,6)+(40 \% \times 4,3)=3,88$
c. Pegawai 3
$\mathrm{Ni}=(60 \% \times 4,5)+(40 \% \times 4,6)=4,54$
d. Pegawai 4
$\mathrm{Ni}=(60 \% \times 4,2)+(40 \% \times 4,6)=4,36$
e. Pegawai 5
$\mathrm{Ni}=(60 \% \times 4)+(40 \% \times 4,3)=4,12$

\section{2) Sikap Kerja}
a. Pegawai 1
$\mathrm{Ns}=(60 \% \times 2,3)+(40 \% \times 4,5)=3,18$
b. Pegawai 2
Ns $=(60 \% \times 3)+(40 \% \times 4,5)=3,6$
c. Pegawai 3
$\mathrm{Ns}=(60 \% \times 4,5)+(40 \% \times 4,2)=4,38$
d. Pegawai 4
$\mathrm{Ns}=(60 \% \times 4,3)+(40 \% \times 4,5)=4,38$
e. Pegawai 5
Ns $=(60 \% \times 3)+(40 \% \times 4,5)=3,6$

\section{3) Perilaku}
a. Pegawai 1
$\mathrm{Np}=(60 \% \times 3,5)+(40 \% \times 4,75)=4$
b. Pegawai 2 $\mathrm{Np}=(60 \% \times 3,5)+(40 \% \times 4,75)=4$
c. Pegawai 3 $\mathrm{Np}=(60 \% \times 3,75)+(40 \% \times 4,25)=3.95$
d. Pegawai 4 $\mathrm{Np}=(60 \% \times 3,5)+(40 \% \times 4,75)=3,95$
e. Pegawai 5 $\mathrm{Np}=(60 \% \times 4)+(40 \% \times 4,5)=4,2$

\section{Perhitungan Penentuan Ranking}

Hasil akhir dari pencocokan profil adalah ranking dari kandidat yang diajukan untuk mengisi suatu jabatan tertentu. Penentuan ranking mengacu pada hasil perhitungan tertentu. Perhitungan tersebut bisa ditunjukkan dengan rumus di bawah ini:

Ranking $=(\%) \mathbf{N i}+(\%) \mathbf{N s}+(\%) \mathbf{N p}$

\section{1) Kapasitas intelektual}
a. Pegawai 1
$\mathrm{R}=(45 \% \times 3,48)+(30 \% \times 3,18)+(25 \% \times 4)$
Ranking $=1,566+0,954+1$
Ranking $=3,52$
b. Pegawai 2
Ranking $=1,746+1,08+1$
$\mathrm{R}=(45 \% \times 3,88)+(30 \% \times 3,6)+(25 \% \times 4)$
Ranking $=3,826$
c. Pegawai 3
$\mathrm{R}=(45 \% \times 4,54)+(30 \% \times 4,38)+(25 \% \times 3,95)$
Ranking $=2,043+1,314+0,9875$
Ranking $=4,3445$
d. Pegawai 4
$\mathrm{R}=(45 \% \times 4,36)+(30 \% \times 4,38)+(25 \% \times 3,95)$
Ranking $=1,962+1,314+0,9875$
Ranking $=4,2635$
e. Pegawai 4
$\mathrm{R}=(45 \% \times 4,12)+(30 \% \times 3,6)+(25 \% \times 4,5)$
Ranking $=1,854+1,08+1,125$
Ranking $=4,059$

Tabel 11. Hasil Perhitungan Ranking

\begin{tabular}{ccc}
\hline No & $\begin{array}{c}\text { ID } \\
\text { Pegawai }\end{array}$ & $\begin{array}{c}\text { Hasil } \\
\text { Akhir }\end{array}$ \\
\hline 1 & 0010 & 3,52 \\
2 & 0017 & 3,826 \\
$\mathbf{3}$ & $\mathbf{0 0 2 0}$ & $\mathbf{4 , 3 4 4 5}$ \\
4 & 0022 & 4,2635 \\
5 & 0032 & 4,059 \\
\hline
\end{tabular}

Dari hasil ranking yang telah dihitung, maka yang mempunyai kesempatan untuk naik jabatan adalah pegawai dengan:

\section{Id : 0020 \\ Nilai : 4,3445}

\section{Implementasi Sistem}

Menu Login merupakan form tampilan awal dari aplikasi sistem penunjang keputusan ini. Gambar 2 menunjukkan tampilan menu Login 


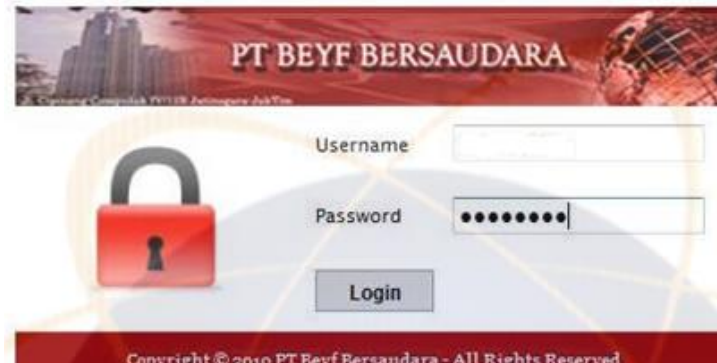

Cogyright 8 a010 PT Beyf Bersaudara - All Rights Reserved

Gambar 2 Tampilan Menu Login

Pada halaman utama terdapat beberapa menu yaitu, data unit kerja, data pegawai, pemilihan dan ganti password, Gambar 3 menunjukkan tampilan halam utama

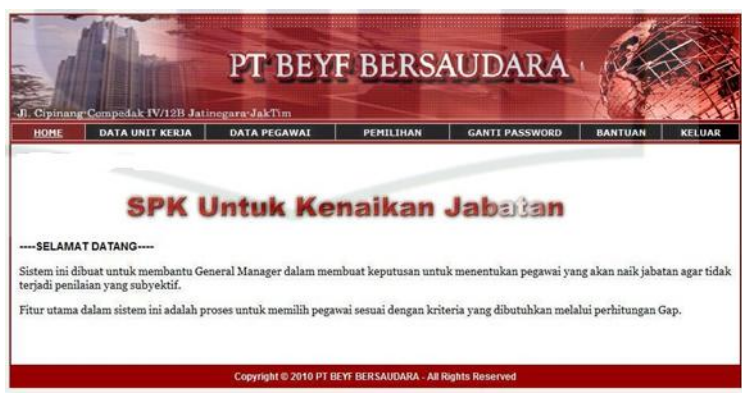

\section{Gambar 3 Halaman Utama}

Pada halaman pemlihan unit kenomor jabatan dan nama jabatan berdasarkan kriteria, untuk lebih jelas nya dapat dilihat seperti gambar 4 berikut

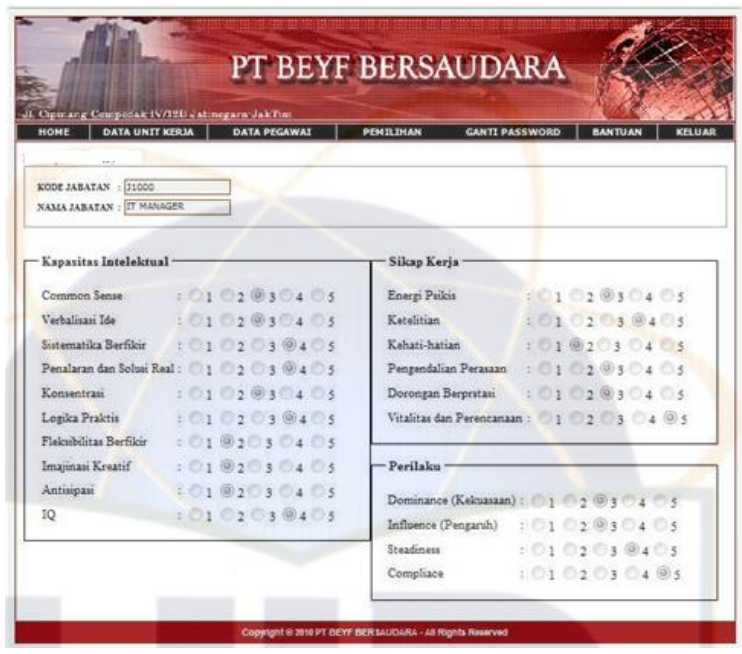

Gambar 4 Halaman Unit kerja

Pada gambar 5 menunjukan tampilan halam hasil akhir daftar nama-nama pegawai yang sudah terdaftar di PT. Beyf bersaudara seperti berikut.

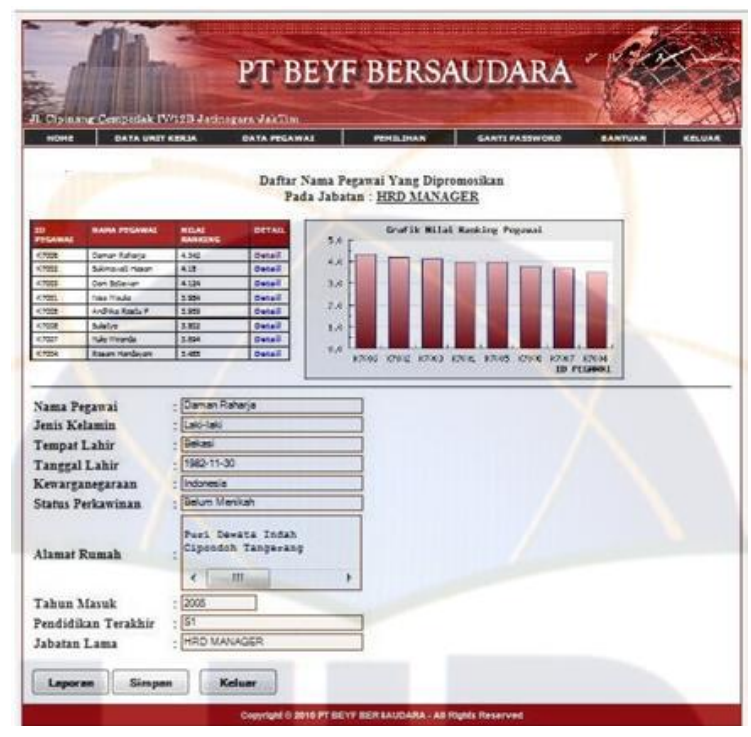

Gambar 5 Halaman nama naam pegawai yang di promosikan

\section{KESIMPULAN DAN SARAN \\ 5.1. Kesimpulan}

Berdasarkan uraian yang telah dijelaskan pada bab-bab sebelumnya, maka dapat disimpulkan bahwa:

1. Dalam proses kenaikan jabatan yang berlangsung pada PT.Beyf Bersaudara masih dilakukan secara manual dan bersifat subyektif, yaitu tidak sesuai dengan kenyataan dan melalui proses yang sangat rumit, seperti adanya pegawai yang dinilai dari satu kriteria saja, tetapi langsung mendapatkan kenaikan jabatan, padahal pegawai tersebut belum tentu unggul pada kriteria-kriteria yang lainnya. Hal tersebut terjadi karena tidak adanya sistem yang dapat membantu para pengambil keputusan dalam menentukan pegawai yang berhak untuk naik jabatan sesuai dengan nilai kriteria yang dibutuhkan.

2. Merancang suatu Sistem Pendukung Keputusan untuk kenaikan jabatan berfungsi untuk membantu General Manager pada PT. Beyf Bersaudara menentukan pegawai yang berhak untuk naik jabatan melalui perhitungan pencocokan profil.

3. Sistem yang dirancang dapat meng-cover proses pemberian standar atau bobot penilaian kinerja pegawai. 
4. Hasil akhir yang dicapai merupakan data yang akurat karena melalui rangkaian proses perhitungan. Sistem yang dibuat sudah memenuhi kriteria yang dibutuhkan dalam memilih pegawai yang akan menduduki jabatan yang lebih tinggi.

\subsection{Saran}

Berdasarkan simpulan yang telah dikemukakan, dapat diajukan beberapa saran untuk pengembangan. Untuk peneliti selanjutnya diharapkan proses analisis dilakukan sampai pada tahap penerapan.

\section{DAFTAR PUSTAKA}

Alter, Steven. 1992. Information System: A Management Perspective. The Benjamin/Cummings Publishing Company, inc.

Armstrong dan Baron. 1998. Personnel Human Resource Management. Macmilan Publishing Company.New York.

Bonczek, R. H., C. W. Holsapple, and Whinston, A. B. 1980. The Evolving Roles of Models in Decision Support Systems. Decision Sciences, Vol. 11No.2 Departemen Pendidikan Nasional. 2002. Kamus Besar Bahasa Indonesia.

Jogiyanto. 2005. Analisis dan Disain Sistem Informasi: Pendekatan Terstruktur Teori dan Praktek Aplikasi Bisnis. Yogyakarta: Andi.

Keen, P. G. W. 1980. Adaptive Design for Decision Support Systems. Data Base, Vol. 12, Nos. 1, 2.

Kusrini, Konsep dan Aplikasi Sistem Pendukung Keputusan. 2007. Yogyakarta: Andi

Little, J. D. C. 1970. Models and Managers: The Concept of a Decision Calculus. Management Science, Vol. 16, No. 8.

Moekijat. 2008. Analisis Jabatan. Bandung: CV Mandar Maju 